\title{
COMMENTS
}

\section{THE IINCOLN MILLS CASE AND SPECIFIC ENFORCEMENT OF NO-STRIKE CLAUSES IN THE FEDERAL COURTS}

Recent decisions have given rise to perplexing difficulties involving the relationship between Section 301 of the Labor Management Relations Act ${ }^{1}$ and the Norris-LaGuardia Act. ${ }^{2}$ In Textile Workers v. Lincoln Mills, ${ }^{3}$ the Supreme Court held that the Norris-LaGuardia Act did not prevent the federal courts from granting specific performance of an arbitration clause under Section 301. Subsequently, in Bull Steamship Co. v. Seafarers' International Union, ${ }^{4}$ the Second Circuit Court of Appeals held that despite the provisions of that section the Norris-LaGuardia Act precluded the specific enforcement of a no-strike clause. ${ }^{5}$ The intimate connection between arbitration clauses and no-strike clauses, emphasized by the Court in the Lincoln Mills case, brings into question the justification for such a disparate application of the NorrisLaGuardia Act.

\section{I}

The relationship between Section 301 and the Norris-LaGuardia Act has for some time generated controversy among both courts and commentators. Out of this controversy, four distinct positions have evolved.

\section{The literal position.}

The advocates of the literal position contend that the provisions of the Norris-LaGuardia Act prevent the federal courts from granting any equitable

161 Stat. 156 (1947), 29 U.S.C.A. $\$ 185$ (1956). $\$ 301(a)$, the subsection material here, reads: "Suits for violation of contracts between an employer and a labor organization representing employees in an industry affecting commerce as defined in this Act, or between any such labor organizations, may be brought in any district court of the United States having jurisdiction of the parties, without respect to the amount in controversy or without regard to the citizenship of the parties."

247 Stat. 70 (1932), 29 U.S.C.A. $\$ \S 101-15$ (1956).

${ }^{3} 353$ U.S. 448 (1957).

${ }^{4} 250$ F.2d 326 (C.A. 2d, 1957), cert. denied 355 U.S. 932 (1958).

5 The strike involved in the Bull Steamship case was in support of contractual modifications sought by the union in line with re-opening provisions in the contract between the parties. As such, this case actually presents problems not strictly parallel to those involved where the strike stems from minor grievances. There is, for example, a serious problem as to whether the no-strike clause should be construed to apply to such a strike. In the absence of clear language to the contrary, it would seem that it should not be so construed, since such a construction would render the re-opening provisions almost meaningless. Inasmuch as the opinion of the Second Circuit Court of Appeals does not take into account any possibly distinguishing factors, this decision will be treated as though it applies with equal force to all strikes in breach of contract. 
relief under Section 301, except where the jurisdictional prerequisites of Section $7^{6}$ are satisfied. Their contention is that the meaning of the Act is so clear that no resort to its underlying policy is necessary, or even proper. The argument that the restrictions of the Act have been repealed by the enactment of Section 301 is rejected on the ground that an act of such major significance in the pattern of national labor policy would hardly be repealed by implication. Further, it is pointed out that the legislative history of Section 301 fails to indicate an intent on the part of Congress to repeal the Act. ${ }^{7}$

\section{The "labor dispute" position.}

The proponents of the "labor dispute" position contend that strikes in breach of contract are not "labor disputes" within the meaning of the NorrisLaGuardia Act. ${ }^{8}$ Under this view, the prohibitions of the Act do not apply to cases under Section 301, whether the action be for specific performance of an arbitration clause or for an injunction against a threatened strike. This argument is supported by reference to the policy in favor of collective bargaining expressed in Section 2 of the Act. ${ }^{9}$ Such an act should not, it is urged, be construed to hamper enforcement of the product of the very activity it sought to foster. ${ }^{10}$

\section{The partial repeal position.}

Results identical to those achieved by the labor dispute position, have been reached by a different approach. The advocates of the partial repeal position do not challenge the proposition that the Norris-LaGuardia Act originally restricted the jurisdiction of the federal courts to grant equitable relief in disputes arising out of collective bargaining agreements. But, they contend, the enactment of Section 301 operated to remove those restrictions. Thus, in order to determine whether a given form of equitable relief is available under Section 301, it is necessary to look to the policy of that section as well as

847 Stat. 70 (1932), 29 U.S.C.A. $\$ 107$ (1956). Under this section the employer must show violence, irreparable injury, and an inability on the part of local authorities to offer adequate protection.

${ }^{7}$ The following cases support the literal position: United Steelworkers v. Galland-Henning Mfg. Co., 139 F.Supp. 630 (E.D. Wis., 1956); United Packing House Workers v. Wilson \& Co., 80 F.Supp. 563 (N.D. Ill., 1948). See also district court opinions in Newspaper Guild v. Boston Herald-Traveler, 140 F. Supp. 759 (D. Mass., 1955), rev'd 233 F.2d 102 (C.A. 1st, 1956); Local 205, United Electrical Workers v. General Electric Co., 129 F.Supp. 665 (D. Mass., 1955) rev'd 233 F.2d 85 (C.A. 1st, 1956), aff'd 353 U.S. 547 (1957).

8 The restrictions of the Norris-LaGuardia Act apply only to "labor disputes." 47 Stat. 70 (1932), 29 U.S.C.A. \$101 (1956).

${ }^{2} 47$ Stat. 70 (1932), 29 U.S.C.A. \$102 (1956).

${ }^{10}$ No federal case adopting the "labor dispute" position has been found. For a discussion of its application by state courts to similar anti-injunction statutes and an argument in favor of its adoption by the federal courts, see Rice, A Paradox of Our National Labor Law, 34 Marq. L. Rev. 233 (1951). 
the Norris-LaGuardia Act. Section 301 constitutes a grant of general jurisdiction to the federal courts over breaches of collective bargaining agreements. In the face of this unrestricted grant, the jurisdictional limitations imposed by the Norris-LaGuardia Act cannot stand, whether the action be for specific performance of an arbitration clause or for an anti-strike injunction. As a matter of policy, the result entailed by the partial repeal position is defended on the grounds that the economic context in which the NorrisLaGuardia Act became law no longer obtains. Section 301 should be read as congressional recognition of the fact that the contemporary economic context requires enforcement of collective bargaining agreements. ${ }^{11}$

\section{The Magruder position.}

Perhaps the most ingenious approach to this problem was recently adopted by Judge Magruder. ${ }^{12}$ The Magruder position differs in result from each of those above-mentioned in that it would allow some, but not all, equitable relief under Section 301. It admits that the restrictions of the Norris-LaGuardia Act were applicable to some disputes now covered by Section 301 and rejects the contention that any part of the Act has been repealed by the later enactment; it denies, however, that the effect of the Act was to restrict all equitable relief. Anti-strike injunctions are prohibited because they would conflict with the express provisions of Section $4 .{ }^{13}$ But the question as to whether other forms of equitable relief are similarly restricted can be answered only after proper analysis of Section 7. The test which determines whether a given form of equitable relief is an "injunction"14 within the meaning of that section is the appropriateness of its requirements to the relief asked. Under this test, Judge Magruder, writing for the Court of Appeals for the First Circuit, held that a decree for specific performance of an arbitration clause was not barred by the restrictions of the Norris-LaGuardia Act. ${ }^{15}$

II The only judicial pronouncement clearly in favor of this position is contained in the district court opinion in Bull Steamship Co. v. Seafarers' International Union, 155 F.Supp. 739 (E.D. N.Y., 1957), rev'd 250 F.2d 326 (C.A. 2d, 1957), cert. denied 355 U.S. 932 (1958). See also Cox, Grievance Arbitration in the Federal Courts, 67 Harv. L. Rev. 591, 602-5 (1954).

12 This position was set forth in The Specific Enforcement of Collective Bargaining Agree. ments under Section 301 (a) of the Taft-Hartley Act, 21 U. of Chi. L. Rev. 251, 264-65 (1954). See also Textile Workers v. American Thread Co., 113 F.Supp. 137 (D. Mass., 1953).

1347 Stat. 70 (1932), 29 U.S.C.A. \$104 (1956).

${ }^{14}$ Section 7 restricts the jurisdiction of the federal courts to grant a "temporary or permanent injunction." 47 Stat. 70 (1932), 29 U.S.C.A. \$107 (1956).

${ }^{15}$ Local 205, United Electrical Workers v. General Electric Co., 233 F.2d 85 (C.A. 1st, 1956), aff'd 353 U.S. 547 (1957). The Magruder position has subsequently been adopted in Bull Steamship Co. v. Seafarers' International Union, 250 F.2d 326 (C.A. 2d, 1957), cert. denied 355 U.S. 932 (1958). 
II

In the Lincoln Mills case, the Supreme Court was confronted with the necessity of determining the relationship between Section 301 and the NorrisLaGuardia Act. In sanctioning specific performance of an agreement to arbitrate grievances, the Court was also faced with another, closely related, difficulty, i.e., the common law rule prohibiting specific enforcement of executory agreements to arbitrate. ${ }^{16}$ An appreciation of the Court's position on this latter problem is a prerequisite for proper interpretation of its discussion concerning the effect of the Norris-LaGuardia Act.

The Court found the necessary statutory mandate for the specific enforcement of arbitration agreements in Section 301 itself. ${ }^{17}$ This feat was accomplished, not by reliance upon the express language of the section, but rather by resort to a discussion of the underlying policy expressed in the legislative history. The Court viewed this policy as giving "[s] tatutory recognition of the collective agreement as a valid, binding, and enforceable contract" and as making these contracts "equally binding and enforceable on both parties."18 In considering the application of this doctrine of equal enforceability to arbitration clauses, the Court referred to the fact that "the agreement to arbitrate grievance disputes is the quid pro quo for an agreement not to strike."19 Without any discussion as to the enforceability of no-strike clauses, the Court thereupon concluded that agreements to arbitrate are specifically enforceable. The coupling of these two clauses compels the conclusion that the Court's determination as to the specific enforceability of the quid (the arbitration clause) was based on the assumption that the quo (the no-strike clause) was also subject to specific enforcement. ${ }^{20}$

It is in the light of this reasoning that the Court's ambiguous remarks regarding the Norris-LaGuardia Act must be evaluated. At the outset, it seemed that the Court would premise its conclusion upon an acceptance of the Magruder position. Reference was made to Judge Magruder's contention

${ }^{16}$ See cases cited by Frankfurter, J., dissenting in Textile Workers v. Lincoln Mills, 353 U.S. 448, 466 (1957).

${ }^{17}$ See Local 205, United Electrical Workers v. General Electric Co., 353 U.S. 547, 548 (1957).

${ }^{18}$ Textile Workers v. Lincoln Mills, 353 U.S. 448, 454 (195\%). In the course of its opinion the Court quoted voluminously from congressional debates in reference to the purpose of the section. Most of the quoted language indicates that the primary purpose of the section was to ensure the enforceability of collective bargaining contracts against unions, thereby achieving equal enforceability.

${ }^{19} \mathrm{Id}$., at 455.

${ }^{20}$ A contrary conclusion would leave the employer without a sufficient remedy in any case where damages were inadequate. That such cases can arise is recognized in the Norris-LaGuardia Act itself in that it is one of the prerequisites to federal jurisdiction set out in Section 7 . 
that the requirements of the Act were "inapposite"21 as applied to specific enforcement of arbitration. Section $8^{22}$ was pointed to as indicating "a congressional policy toward settlement of labor disputes by arbitration." ${ }^{223}$

The Court embarked however upon an entirely different line of reasoning, without any explicit attention to the difference. It cited a series of cases holding in effect that the prohibitions of the Norris-LaGuardia Act had been partially repealed insofar as they conflicted with the policies of subsequent statutes. ${ }^{24}$ Although none of these cases involved a direct conflict with Section $4,{ }^{25}$ it seems unlikely that the Supreme Court will choose to distinguish them on this ground. In an opinion handed down on the same day that the Lincoln Mills case was argued, this same series of cases was used as authority for the issuance of an anti-strike injunction, directly contrary to Section $4 .^{28}$

The reliance of the Court upon these cases suggests that the inapplicability of the Norris-LaGuardia Act stems from a conflict with Section 301 rather than from an inappositeness of the provisions of the Act itself. Since any such conflict, in view of the generality of the language of Section $301,{ }^{27}$ presents itself with equal force in the case of a no-strike clause, this reliance gives added impetus to the notion that anti-strike injunctions are available. On the other hand, the Court's discussion of Section 8 and its use of the term "inapposite" clearly indicate the presence of some uncertainty on this point. Thus, the Court could eventually conclude that a proper reconciliation of the policies of the two statutes would permit the specific enforcement of

${ }^{21}$ Textile Workers v. Lincoln Mills, 353 U.S. 448, 458 (1957). This term was quoted from Judge Magruder's opinion in Local 205, United Electrical Workers v. General Electric Co., 233 F.2d 85, 92 (C.A. 1st, 1956).

${ }^{22} 47$ Stat. 70 (1932), 29 U.S.C.A. \$108 (1956).

${ }^{23}$ Textile Workers v. Lincoln Mills, 353 U.S. 448,458 (1957).

24 The Court cited the following cases: Virginian Railway Co. v. System Federation, 300 U.S. 515 (1937); Graham v. Brotherhood of Firemen, 338 U.S. 232 (1949); Syres v. Oil Workers International Union, 350 U.S. 892 (1955). While the Court in these cases did not specifcally refer to partial repeal, it premised its refusal to apply the Norris-LaGuardia Act upon policies created by subsequent statutes.

${ }^{25}$ Virginian Railway Co. v. System Federation, 300 U.S. 515 (1937), involved an injunction directing an employer to negotiate with the employees' representatives. Graham v. Brotherhood of Firemen, 338 U.S. 232 (1949), involved an injunction against a union restraining racial discrimination in its representation of employees. The duties enforced in each of these cases were imposed by the Railway Labor Act after the enactment of the Norris-LaGuardia Act. 44 Stat. 577 (1926), 48 Stat. 926 (1934), as amended, 45 U.S.C.A. \$\$151-88 (1954). Syres v. Oil Workers International Union, 350 U.S. 892 (1955), involved an injunction similar to that in the Graham case where the duty enforced was imposed by the National Labor Relations Act, 49 Stat. 449 (1935), as amended, 61 Stat. 136 (1947), 29 U.S.C.A. \$\$151-66 (1956).

${ }^{25}$ Brotherhood of Railroad Trainmen v. Chicago River \& Indiana R. Co., 353 U.S. 30, 41-42 (1957).

${ }^{27}$ See Labor-Management Relations-Availability of Mandatory Relief to Management for Breach of No-Strike Clause in Collective Bargaining Agreement, 33 N.Y.U.L. Rev. 225 (1958). 
arbitration clauses, ${ }^{28}$ but prohibit similar enforcement of no-strike clauses. However, the central importance of the Court's emphasis upon the intimate relationship between arbitration and no-strike clauses as well as its extensive discussion of the need for equal enforceability cannot be ignored. Considered as a whole, it seems doubtful that the Court's opinion should be taken as indicating that there is any difference in the attitude of our national labor laws toward these clauses of such a nature as would justify differential enforceability.

Thus, the conclusion is reached that the Lincoln Mills case should be regarded as having adopted the repeal position, as to no-strike as well as arbitration clauses. The literal position was rejected by the holding of the case. The fact that the Court never questioned the assumption that it was deciding a "labor dispute" clearly indicates a refusal to adopt that position. The Magruder position was impliedly rejected in that it is inconsistent with the doctrine of equal enforceability pronounced by the Court.

One further obstacle may block the conclusion that the Lincoln Mills case should be interpreted as deciding that the restrictions of the Norris-LaGuardia Act are repealed as to all suits under Section 301. Prior to the Lincoln Mills case, the vast majority of the lower federal courts which had entertained suits for specific performance of arbitration clauses had held that such relief was available. ${ }^{29}$ Where anti-strike injunctions were sought, the weight of authority was to the contrary..$^{30}$ In most of the former cases, no

${ }^{28}$ Such a conclusion could be buttressed by reference to other pronouncements of congressional policy in favor of arbitration. See, e.g., $\$ \$ 101(1), 201(b)$, and 203(d) of the Taft-Hartley Act. But the exclusion of collective bargaining agreements from the Arbitration Act represents a contrary policy. 43 Stat. 883 (1925), 9 U.S.C.A. $\$ \$ 1-14(1953)$. It is noteworthy that the Court did not refer to any of these indications of policy.

${ }^{29}$ Local 205, United Electrical Workers v. General Electric Co., 233 F.2d 85 (C.A. 1st, 1956), aff'd 353 U.S. 547 (1957); Newspaper Guild v. Boston Herald-Traveler, 233 F.2d 102 (C.A. 1st, 1956); United Textile Workers v. Goodall-Sanford, Inc., 233 F.2d 104 (C.A. 1st, 1956), aff'd 353 U.S. 550 (1957); International Union v. Buffalo-Springfield Roller Co., 131 F.Supp. 667 (S.D. Ohio, 1954); Wilson Brothers v. Textile Workers Union, 132 F.Supp. 163 (S.D. N.Y., 1954), appeal dismissed 224 F.2d 176 (C.A. 2d, 1955); Evening Star Newspaper Co. v. Columbia Typographical Union, 124 F.Supp. 322 (D. D.C., 1954); Insurance Agents International Union v. Prudential Insurance Co., 122 F.Supp. 869 (E.D. Pa., 1954); Local 207, etc. v. Landers Frary \& Clark, 119 F.Supp. 877 (D. Conn., 1954); Textile Workers Union v. American Thread Co., 113 F.Supp. 137 (D. Mass., 1953); Local 379, etc. v. Jacobs Mfg. Co., 120 F.Supp. 228 (D. Conn., 1953); Textile Workers v. Aleo Mfg. Co., 94 F.Supp. 626 (N.D. N.C., 1950) ; Mountain States Division No. 17 v. Mountain States Telephone \& Telegraph Co., 81 F.Supp. 397 (D. Colo,, 1948). Contra: United Steelworkers v. Galland-Henning IIfg. Co., 139 F.Supp. 630 (E.D. Wis., 1956), aff'd 241 F.2d 323 (C.A. 7th, 1957), rev'd 354 U.S. 906 (1957); Newspaper Guild of Pawtucket v. Times Publishing Co., 131 F.Supp. 499 (D. R.I., 1955); United Packing House Workers v. Wilson \& Co., 80 F.Supp. 563 (N.D. Ill., 1948).

${ }^{30}$ W. L. Mead, Inc. v. International Brotherhood of Teamsters, 217 F.2d 6 (C.A. 1st, 1954); Alcoa S. S. Co. v. MIcMahon, 81 F.Supp. 541 (S.D. N.Y., 1948), aff'd 173 F.2d 567 (C.A. 2d, 1949) cert. denied 338 U.S. 821 (1949); Sound Lumber Co. v. Lumber \& Sawmill Workers Local Union, 122 F.Supp. 925 (N.D. Cal., 1954). 
real consideration was given to the question of the applicability of the NorrisLaGuardia Act. It may be contended that the Lincoln Mills case represents no more than a willingness on the part of the Supreme Court to rely upon the weight of authority on what must be considered a point of relatively minor importance in the case. ${ }^{31}$ The Court may, therefore, not feel itself bound by the broad language in its opinion when it is called upon to decide a case involving a suit for an injunction against a strike. This argument cannot be lightly dismissed. On the other hand, a future holding that no-strike clauses cannot be specifically enforced would seem to be inconsistent with the basis of the Lincoln Mills decision.

\section{III}

The above interpretation of the Lincoln Mills case seems necessary in order to render the Court's reasoning consistent with its view of the policy of Section 301. Nevertheless the opinion is tinged with some ambiguity and could be interpreted as adopting the Magruder position. It is proposed to examine the justification for such an interpretation.

In the Bull Steamship case, the Court of Appeals for the Second Circuit interpreted the Lincoln Mills case as adopting the Magruder position in order to avoid a direct conflict with the provisions of Section 4 of the NorrisLaGuardia Act. The Court rejected the repeal position primarily upon the grounds that it involved a repeal by implication of a statute of such major importance that serious doubts must be entertained that Congress would have adopted such a course. This argument was buttressed by reference to the fact that in other sections of the Taft-Hartley Act, Congress expressly removed the restrictions of the Norris-LaGuardia Act insofar as they applied to those sections. ${ }^{32}$ In addition, the legislative history of Section 301 fails to reveal a congressional intent to effect a repeal.

Ample precedent is available, however, to indicate that such rules of construction have seldom been strictly adhered to where the Norris-LaGuardia Act is involved. On the contrary, the Supreme Court has repeatedly held that Act to have been repealed by implication where such a holding facilitates the effective enforcement of later statutes. ${ }^{33}$ The justification for this attitude

31 The major question decided in the Lincoln Mills case was whether Section 301 provided a federal substantive law of collective bargaining and the constitutional implications connected therewith. For a discussion of this question, see Cox, Federalism in the Law of Labor Relations, 67 Harv. L. Rev. 1297 (1954); Mendelsohn, Enforceability of Arbitration Agreements under Taft-Hartley Section 301, 66 Yale L. J. 167 (1956); Wollett and Wellington, Federalism and Breach of the Labor Agreement, 7 Stan. L. Rev. 445 (1955).

${ }^{32}$ The court pointed to Sections 101(h), 208(b), and 302(e), 29 U.S.C.A. $\$ \$ 160(\mathrm{~h}), 178(\mathrm{~b})$, 186(e) (1956). 250 F.2d 326, 330 (C.A. 2d, 1957).

${ }^{33}$ Virginian Railway Co. v. System Federation, 300 U.S. 515 (1937); Graham v. Brotherhood of Firemen, 338 U.S. 232 (1949); Syres v. Oil Workers International Union, 350 U.S. 892 (1955); Brotherhood of Railroad Trainmen v. Chicago River \& Indiana R. Co., 353 U.S. 30 (1957). 
lies in the obvious disparity between the scope of the Act as drafted and the purpose it sought to accomplish. The principal objective of the Act was to prohibit the use of the labor injunction as a means of thwarting the effective assertion of economic power in the collective bargaining process. ${ }^{34}$ To further this objective, the Act was drafted in sweeping terms, with the consequent effect of prohibiting practically all injunctions in labor disputes, ${ }^{35}$ including all injunctions against peaceful strikes. As a result of this disparity, the courts have quite often felt free to inquire, not only into whether an injunction violates the express language of the Act, but also, whether such an injunction contravenes its underlying policy. ${ }^{36}$ Where there is no conflict of policy, injunctions have been upheld by the finding of an implied repeal. ${ }^{37}$

In Brotherhood of Railroad Trainmen v. Chicago River \& Indiana R. Co.,38 the Supreme Court made its use of this procedure explicit. In upholding an injunction against a threatened strike in a suit brought by an employer against a union under the Railway Labor Act, ${ }^{39}$ the Court viewed its task as one of reconciling the policies of two parts of the "pattern of labor legislation." 40 Inasmuch as the injunction sought did not contravene the policy of the Norris-LaGuardia Act, the Court refused to be bound by the rule against repeals by implication. ${ }^{41}$

The good sense underlying this position is particularly apparent in a situation such as that presented by Section 301. If the legislative history of that Section reveals anything, it reveals that Congress was not entirely cognizant of the ramifications that the enactment of the Section would have. ${ }^{42}$ It has now been settled that Section 301 operates as a mandate to the federal courts to develop a body of law governing collective bargaining contracts in industries affecting interstate commerce, ${ }^{43}$ a consequence Congress may well not have foreseen. It would be unrealistic to assume that Congress ever felt called upon to decide what relationship such a mandate should have to the NorrisLaGuardia Act.

3447 Stat. 70 (1932), 29 U.S.C.A. $\$ 102$ (1956); Brotherhood of Railroad Trainmen v. Chicago River \& Indiana R. Co., 353 U.S. 30 (1957). For an argument that the philosophy behind the Norris-LaGuardia Act was the belief that courts should not intervene in labor disputes, see Frankfurter and Greene, The Labor Injunction (1930).

${ }^{35}$ Certain injunctions may issue under the Act if the procedural requirements in Section 7 are met. Under the Magruder position, certain injunctions are not subject to the requirements of the Act.

${ }^{36}$ See cases note 33 supra. $\quad{ }^{37}$ Ibid. $\quad{ }^{38} 353$ U.S. 30 (1957).

3944 Stat. 577 (1926), as amended, 45 U.S.C.A. $\$ \$ 151-88$ (1954).

10 Brotherhood of Railroad Trainmen v. Chicago River \& Indiana R. Co., 353 U.S. 30, 41 (1957).

41 Again the Court refrained from the specific use of the term "repeal." See note 24 supra.

42 See legislative history in appendix to Justice Frankfurter's dissenting opinion, Textile Workers v. Lincoln Mills, 353 U.S. 448, 485-546 (1957).

${ }^{13}$ Textile Workers v. Lincoln Mills, 353 U.S. 448, 456 (1957). See note 31 supra. 
Once it is recognized that inflexible application of the rule against repeals by implication is not required, the argument in favor of the Magruder position loses much of its force. A holding that anti-strike injunctions are not available under Section 301, simply because of a conflict with the language of Section 4, would constitute a too strict reliance upon the language of the Norris-LaGuardia Act, contrary to the rule adopted in the Chicago River case. In line with this rule, a more proper approach would seem to be the reconciliation of the policies of the two statutes.

The Supreme Court has said that the body of law to be created pursuant to Section 301 is to be gleaned from the policy of national labor legislation. ${ }^{44}$ In this process, the policy of Section 301 itself is undoubtedly to be considered. The policy of this section is clearly one in favor of increased judicial enforcement of collective bargaining contracts. By its enactment, Congress has brought federal power to bear in a field previously subject only to state regulation. During the period of state regulation, injunctions against strikes in breach of contract were available in many states. ${ }^{45}$ The continued availability of such remedies in those states will probably depend upon the rule adopted by the federal courts. ${ }^{46}$ Thus, a holding that the Norris-LaGuardia Act is applicable to suits under Section 301 would probably create a situation in which responsibility under collective bargaining contracts would have been diminished rather than increased, in direct conflict with the policy of the section.

In addition, it should be pointed out that the adoption of the repeal position facilitates the realization of other policy objectives embodied in national labor legislation. By removing the possibility of a strike as a method of settling disputes arising under a collective bargaining contract, the parties would be encouraged to come to regard arbitration as an indispensable method of settling disputes. The inevitable result would be a strengthening of the arbitration process, an objective long sought and reflected in national labor legislation. ${ }^{47}$ The cost of such an improvement would be minimal. Unions would be deprived of the right to strike only for such a period of time as they had agreed to be so deprived. It is difficult to visualize how such a voluntary deprivation could impair the bargaining position of labor. On the contrary,

44 Textile Workers v. Lincoln Mills, 353 U.S. 448, 456 (1957).

${ }^{45}$ See Rice, A Paradox of Our National Labor Law, 34 Marq. L. Rev. 233 (1951).

${ }^{46}$ There is some question, of course, whether state courts will be allowed to exercise concurrent jurisdiction under Section 301 . If not, injunctions by a state court would be impossible. If, on the other hand, concurrent jurisdiction is permitted, it seems highly probable that the requirements of uniformity will be held to require that state courts should be allowed to grant only such remedies as are available in the federal courts. For an argument to this effect, see 58 Col. L. Rev. 278 (1958), criticizing McCarroll v. Los Angeles Council of Carpenters, 315 P.2d 322 (Cal., 1957), cert. denied 355 U.S. 932 (1958)

${ }^{17}$ In addition to Section 8 of the Norris-LaGuardia Act, see $\$ \$ 101(1), 201(\mathrm{~b})$, and 203(d) of the Taft-Hartley Act. 
it seems quite probable that a betterment of its bargaining position may actually result. 48

Support for injunctive enforcement of a no-strike clause may be found in the Chicago River case. ${ }^{49}$ In that case, the union had threatened to strike as a result of grievance disputes arising between the parties. The employer had submitted the disputes to the National Railroad Adjustment Board for settlement under Section 3, First, of the Railway Labor Act. ${ }^{50}$ In reaching the conclusion that the Norris-LaGuardia Act did not prohibit the injunction, the Court lay some stress upon the fact that Congress, in creating the National Railroad Adjustment Board, had required labor to submit to an alternative method of dispute settlement.

The typical situation under Section 301 is a grievance strike in violation of a contract containing both an arbitration clause and a no-strike clause. In such a case the reasonable substitute for self-help has been agreed upon by the parties themselves and made enforceable by Section 301. To allow a strike in such a situation would work a subversion of congressional policy similar to that condemned by the Court in the Chicago River case. ${ }^{51}$ In the more unusual situation of a contract without an arbitration clause, the situation would be no different. Even though the Norris-LaGuardia Act were not applied, the rule embodied in Section 8 of that Act-that a party seeking an injunction first must offer $^{52}$ to submit the dispute to arbitration-would probably survive, inasmuch as it aids rather than conflicts with the policy of Section $301 .^{53}$

${ }^{18}$ As a matter of pure economics, the union would have something more to sell, i.e., an irrevacable promise not to strike, a commodity which could be of some substantial value.

${ }^{49}$ Brotherhood of Railroad Trainmen v. Chicago River \& Indiana R. Co., 353 U.S. 30 (1957).

s0 44 Stat. 578, 48 Stat. 1189 (1934), 45 U.S.C.A. $\$ 153$ (1954).

${ }^{5 I}$ Brotherhood of RajIroad Trainmen v. Chicago River \& Indiana R. Co., 353 U.S. 30, 41 (1957).

32 In Manion v. Kansas City Terminal Ry. Co., 353 U.S. 927 (1957), the Supreme Court vacated an injunction granted by the Kansas City Court of Appeals in a situation similar to the Chicago River case on the grounds that the dispute had not been actually submitted to the NRAB. In view of the procedural difficulties involved in presenting all grievances to the NRAB, this decision is puzzling. Such a rule would seem to have no application in suits under Section 301.

s3 It must, however, be doubted that such a rule would apply where the strike involved was in support of wage demands under a re-opening provision. Where the union has in explicit terms contracted not to strike at re-opening, the employer should be able to obtain an injunction without an offer to arbitrate wages. Insofar as Section 8 would require such an offer, it should be held inapplicable in that it would conflict with the policy of equal enforceability. The power to require specific performance of a no-strike clause would be worth very little if its exercise depended upon such a concession. It seems doubtful that the rule applied in Trainmen v. Toledo P. \& W. R. Co., 321 U.S. 50 (1944) (where it was held that Section 8 applied to economic disputes under the Railway Labor Act) would be adopted in view of subsequent pronouncements condemning compulsory arbitration of economic disputes. See, e.g., Bus Employees v. Wisconsin Board, 340 U.S. 383 (1951). 
Considerations of fairness also support the conclusion that the specific enforcement of arbitration clauses should be accompanied by the specific enforcement of no-strike clauses. Under the Lincoln Mills case, unions are provided with a swift, effective remedy for the enforcement of their rights under collective bargaining contracts. If the Norris-LaGuardia Act is held to apply, employers would be deprived of an equally effective remedy in enforcing the union's only real obligation under most collective bargaining contracts. They may be forced to confine themselves to actions for damages, a clearly inadequate remedy where the showing of irreparable injury prerequisite to the issuance of an injunction is possible.

It is possible, on the other hand, that injunctive relief may be available to employers in certain cases at the instance of the National Labor Relations Board. This possibility would depend upon acceptance by the courts of a theory promulgated by the Board in the Boone County Coal Corporation ${ }^{54}$ and Westmoreland Coal Company ${ }^{55}$ cases. In the Boone case, the Board held that a strike occasioned by a dispute referable to arbitration under the terms of a collective bargaining contract constitutes an attempt to modify the contract within Section 8 (d) of the Taft-Hartley Act.56 In the Westmoreland case, the Board reached a similar conclusion as to a strike occasioned by dissatisfaction with an arbitration award. These decisions effect a considerable broadening of the scope of the good faith bargaining requirements of Section 8 (b) (3), ${ }^{57}$ thus increasing the class of cases in which a strike in breach of contract also constitutes an unfair labor practice and is therefore enjoinable at the instance of the NLRB. ${ }^{58}$

Even under the theories set forth in the Boone and Westmoreland cases, however, not all strikes in breach of contract are unfair labor practices. In those cases which fall without Section $8(\mathrm{~d})$, the need for independent relief under Section 301 is obvious. Where there is an overlap, the need is not so clear. Nevertheless, Section 301 seems to represent a policy of relieving the employer of the necessity of prosecuting his contractual rights before the NLRB. ${ }^{59}$ The difficulties inherent in this cumbersome administrative procedure contrast sharply with the ease with which a union may assert its contract rights under the Lincoln Mills decision.

$$
\begin{aligned}
& { }^{54} 117 \text { N.L.R.B. } 1095 \text { (1957). }{ }^{55} 117 \text { N.L.R.B. } 1072 \text { (1957). } \\
& { }^{56} 61 \text { Stat. } 140 \text { (1947), } 29 \text { U.S.C.A. } \$ 158(d)(1956) . \\
& { }^{57} 61 \text { Stat. } 140 \text { (1947), } 29 \text { U.S.C.A. } \$ 158(\text { b)(3) (1956). } \\
& { }^{58} 61 \text { Stat. } 146 \text { (1947), } 29 \text { U.S.C.A. } \$ 160 \text { (e) (1956). }
\end{aligned}
$$

${ }^{59}$ This, of course, brings into question the problem of the relationship between Section 301 and the unfair labor practice provisions of the Taft-Hartley Act in those cases where the breach of contract also constitutes an unfair labor practice. For an early discussion of this problem, see Wollett and Wellington, Federalism and Breach of the Labor Agreement, 7 Stan. L. Rev. 445, 454 (1955). See also McCarroll v. Los Angeles Council of Carpenters, 315 P.2d 322 (Cal., 1957), cert. denied 355 U.S. 932 (1958); Dunau, Contractual Prohibition of Unfair Labor Practices: Jurisdictional Problems, 57 Col. L. Rev. 52, 81 (1957). 
The doctrine of equal enforceability set forth in the Lincoln Mills case militates against such inequities. This doctrine constitutes judicial recognition of a position long-espoused by many commentators, i.e., that the integrity of the collective bargaining process requires that labor contracts be equally enforced against both parties. ${ }^{60}$ While the feeling persists that judicial intervention in labor disputes is ill-advised, ${ }^{61}$ the enactment of Section 301 constitutes congressional recognition that, at the very least, some kind of judicial remedy should be available for the enforcement of collective bargaining contracts. Moreover, the Lincoln Mills decision blesses judicial enforcement by injunction, at least insofar as arbitration clauses are concerned. It remains only to consider whether different treatment is required in the case of a nostrike clause by the special difficulties that may arise in the enforcement of anti-strike injunctions. It must be admitted that these difficulties may be so acute in particular cases as to override the general policy of enforcement enacted by Section 301. However, the sweeping prohibitions of the NorrisLaGuardia Act operate inflexibly without regard to the difficulties of enforcement in the particular case.

So far as the Norris-LaGuardia Act was intended to take the heat of labor struggles off the courts by relieving them of policing functions-and it may be doubted whether this was even a minor intention of Congress-surely courts can always invoke the self-protecting rule that complexity of supervision is a reason for denying specific relief and leaving the plaintiff to recovery of damages. ${ }^{62}$

Objections to the issuance of anti-strike injunctions under Section 301 might also be premised upon the increased danger of holding union officials personally responsible for situations beyond their control. However, it must be pointed out that the Norris-LaGuardia Act is, at best, a crude tool with which to implement this policy. It seems improbable that the danger of such abuses is less where the jurisdictional prerequisites of Section 7 are met. Moreover, Congress has evidenced a willingness to allow the courts to cope with this problem in other situations. ${ }^{63}$ The question then is really one of balancing the policy enunciated in the Norris-LaGuardia Act with the policy of equal enforceability expressed in Section 301. It seems likely that this later expression of policy will be seen as controlling.

${ }^{60}$ See, e.g., Rice, A Paradox of Our National Labor Iaw, 34 Marq. L. Rev. 233 (1951); The Specific Enforcement of Collective Bargaining Agreements under Section 301(a) of the Taft-Hartley Act, 21 U. of Chi. L. Rev. 251, 265 (1954). See also Cox, Grievance Arbitration in the Federal Courts, 67 Harv. L. Rev. 591, 602-7 (1954), where a similar position is adopted with less enthusiasm.

'See Frankfurter, J., dissenting in Textile Workers v. Lincoln Mills, 353 U.S. 448, 46264 (1957); Shulman, Reason, Contract, and Law in Labor Relations, 68 Harv. L. Rev. 999, 1024 (1955).

62 Rice, A Paradox of Our National Labor Law, 34 Marq. L. Rev. 233, 252 (1951).

${ }^{63}$ See Brotherhood of Railroad Trainmen v. Chicago River \& Indiana R. Co., 353 U.S. 30 (1957). See also, $\$ \$ 101(\mathrm{~h}), 208(\mathrm{~b})$ and 302 (e) of the Taft-Hartley Act., 61 Stat. 136 (1947), 29 U.S.C.A. $\$ \$ 160(\mathrm{~h}), 178(\mathrm{~b}), 186(\mathrm{e})(1956)$. 
Thus, the conclusion is reached that injunctive relief should be generally available under Section 301, notwithstanding the express provisions of a statute enacted in another era for a different purpose. Such a rule encourages the confinement of economic warfare in labor-management relations to disputes which arise in the course of bargaining, leaving the recurrent problems which arise under the terms of existing contracts to more orderly processes of settlement.

\section{LESSOR'S SECURITY ARRANGEMENTS AND THE INTERNAL REVENUE CODE}

One increasingly popular form of landlord protection against defaulting tenants who leave lessors with vacant premises and perhaps falling rentals is the requirement of a substantial deposit upon the execution of the lease. ${ }^{1}$ These deposits are characterized as advance rent or bonuses, in which case the sum may be retained upon default or expiration of the lease, ${ }^{2}$ or as security deposits, the lessors contracting to return that portion not actually needed to pay for defaults. ${ }^{3}$ While a lessor will get the same economic rental benefits from either arrangement, ${ }^{4}$ its characterization has important tax consequences.

1 This procedure has definite advantages over other methods intended to provide security from the commencement of the lease. While a mortgage on other real estate can perhaps be obtained, there are the difficulties of prior claims, recording problems, and the need for some kind of foreclosure before the security can be realized. A surety adds another party to the lease and renders compromises more difficult; a professional surety adds the additional cost of premiums to the tenant's financial load. See Wilson, Lease Security Deposits, 34 Col. L. Rev. 426 (1934).

2 Advance rent: E.g., Galbraith v. Wood, 124 Minn. 210, 144 N.W. 945 (1914) and cases cited in I American Law of Property $\$ 3.73 \mathrm{n} .18$ (1952). The rule allowing the lessor to retain advance rent applicable to a remote future date was criticised in Lessee's Recovery of an Advance Payment of Rent, 25 Ill. L. Rev. 716 (1931).

Bonuses: Wm. Filene's Sons Co. v. Weed, 245 U.S. 597 (1918); In re Sun Drug Co., 4 F.2d 843 (C.A. 9th, 1925); A-1 Garage v. Lange Investment Co., 6 Cal.App.2d 593, 44 P.2d 681 (1935), cert. denied 296 U.S. 642 (1935). There may, however, be a rebate provision. E.g., Wood v. Hepwell, 107 Cal.App. 690, 290 Pac. 1040 (1930). See Methods of Securing Lessor against Rental Defaults on Long Term Leases, 45 Yale L. J. 537 (1936).

${ }^{3}$ See cases on security deposits in Provision in Lease for Pecuniary Forfeiture Where Lease Is Prematurely Terminated, 106 A.L.R. 292 (1937). Occasionally advance rent will be considered a security deposit if its amount is disproportionate to the damages suffered by the lessor. Jensen v. Sparkes, 53 F.2d 433 (C.A. 9th, 1931); Rez v. Summers, 34 Cal.App. 527, 168 Pac. 156 (1917).

${ }^{4}$ Assuming a ten year lease with an annual rent of $\$ 10,000$, the rational landlord will accept $\$ 10,000$ advance rent which he can invest for nine years, or a $\$ 10,000$ security deposit which he can also invest for nine years (assuming the security deposit is returned after the final rental payment is made, at the beginning of the tenth year). If he accepts a bonus he will expect an amount equal to the present value of receiving for nine years an interest annuity equivalent to the interest annuity that can be obtained by investing the advance rent or security deposit, plus an additional amount to compensate him for having a smaller sum to apply in case of breach. 